\title{
Hydroponic Culture of Triticum aestivum as a Model System to Evaluate the Biological Effects of Fusariosis and Fungicides
}

Natalia G. Menzyanova*

Siberian Federal University

79 Svobodny, Krasnoyarsk, 660041, Russia

Received 30.11.2015, received in revised form 10.05.2016, accepted 25.05.2016

The research of the potential of hydroponic culture Triticum aestivum as a model system for the study of the biological effect of fungicides included determination of the content of peroxidation products of lipids (malondialdehyde) and proteins (carbonylated proteins), free proline in roots, and border cells in the root apex of 2-day-old seedlings infected with Fusarium graminearum. In the infected seedlings roots content of proline, carbonylated proteins and border cells was 1.4; 8.0 and 3.0 times, respectively, higher than in roots of non-infected seedlings. Triazole fungicide tebuconazole in the studied concentrations (0.01, 0.10 and $1.00 \mu \mathrm{g} / \mathrm{ml}$ medium) caused a dose-dependent decrease in the number of border cells in the root apex of infected seedlings. The results allow to positively evaluate hydroponic culture Triticum aestivum as a model system for studying of the biological effects of the fungicides (in particular, their phytotoxicity) and fusariosis.

Keywords: hydroponic culture, Triticum aestivum, Fusarium graminearum, products of lipid and protein peroxidation, free proline, border cells, fungicide tebuconazole.

DOI: $10.17516 / 1997-1389-2016-9-2-241-252$.

(C) Siberian Federal University. All rights reserved

* Corresponding author E-mail address: mennage@mail.ru 


\section{Гидропонная культура Triticum aestivum \\ как модельная система \\ для оценки эффектов фузариоза и фунгицидов}

Н.Г. Мензянова

Сибирский федеральный университет Россия, 660041, Красноярск, пр. Свободный, 79

Исследование потенциала гидропонной культуры Triticum aestivum в качестве модельной системы для изучения биологического действия фунгицидных препаратов включало определение содержания продуктов перекисного окисления липидов (малонового диальдегида) и белков (карбонилированных белков), свободного пролина в корнях, количества пограничных клеток в корневом апексе 2-дневных проростков, инфицированных Fusarium graminearum. Показано, что в корнях инфицированных проростков содержание пролина, карбонилированных белков и пограничных клеток было в 1.4, 8.0 и 3 раза выме, чем в корнях неинфицированных проростков. Триазольный фунгиџид тебуконазол в исследованных конщентрациях (0.01; 0.10 и 1.00 мкг/мл среды) в корневом апексе инфицированных проростков вызывал дозозависимое уменьшение численности пограничных клеток. Результаты позволяют положительно оценить гидропонную культуру Triticum aеstivuт как модельную систему для изучения биологических эффектов фунгицидов (в частности, их фитотоксичности) и фузариоза.

Ключевые слова: гидропонная культура Triticum aеstivum, Fusarium graminearum, продукты перекисного окисления липидов и белков, свободный пролин, пограничные клетки, фунгицид тебуконазол.

\section{Введение}

Фузариоз - одно из самых распространенных заболеваний зерновых агрокультур, которое вызывают почвенные патогенные грибы рода Fusarium. Использование фунгицидов позволяет снизить риск развития фузариозов и уменьшить содержание микотоксинов в товарном зерне (Schmale et al., 2003; SANCO, 2013). 30 \% всего рынка фунгицидов представлено триазольными фунгицидами, которые являются потенциальными ингибиторами фунгальной стерол-14- $\alpha$-деметилазы, приводят к нарушению метаболизма стеролов и в итоге к дефициту функций мембранных систем микопатогена (Lamb et al., 2001;
Hartwig et al., 2012). С другой стороны, триазольные фунгициды являются фитотоксикантами (Ahemad et al., 2012 a, b). Специфических эффекторных мишеней для триазольных фунгицидов в растительных клетках не выявлено, на системном уровне их токсические эффекты реализуются в нарушениях гормонального баланса (Yang et al., 2014), азотистого обмена, снижении активности прорастания, нарушениях роста и развития корней (Serra et al., 2013, 2015).

Известно, что фунгальная стерол-14$\alpha$-деметилаза, эффекторная мишень триазольных фунгицидов в клетках микопатогенов, относится к эволюционно древнему 
цитохром-450(СYР)-суперсемейству, которое выявлено также у растений и животных (Lamb et al., 2001). Предполагается, что фитотоксичность (а также токсичность триазольных фунгицидов для человека и животных) связана с влиянием фунгицидов на активность стеролдеметилаз и нарушением стерол-зависимого сигналинга (Hartwig et al., 2012). На системном уровне стерол-зависимый сигналинг определяет активность таких процессов, как пролиферация, дифференцировка, продукция реактивных форм кислорода (РФК) (Wassmann et al., 2001; Park et al., 2008).

Причинно-следственная цепочка «ингибирование стерол-деметилаз $\rightarrow$ дефицит стерол-зависимого сигналинга $\rightarrow$ ингибирование продукции реактивных форм кислорода» представляет особый интерес для оценки мико- и фитотоксичности гербицидов, а также оценки устойчивости растений к микопатогенам. Связано это с тем, что регулируемая гиперпродукция реактивных форм кислорода (РФК) в ответ на инвазию патогенов является одной из важнейших защитных реакций растительных организмов. РФК являются не только высокотоксичными соединениями, но и запускают специфические системы сигналинга, которые приводят к изменению паттернов экспрессии генов и формированию состояния «резистентности» или «чувствительности» растения-хозяина к патогенам (обзоры Frederickson et al., 2014; Swarupa et al., 2014). У патогенных грибов в процессе эволюции сформировались скавенджер-системы, которые позволяют им нейтрализовать цитотоксические эффекты окислительного взрыва растения-хозяина. Кроме того, патогенные грибы стали использовать РФК, которые генерируются в клетках растения-хозяина, для регуляции экспрессии собственных генов, контролирующих процессы клеточной дифференцировки и роста гифов в растительных тканях (Takemoto et al., 2007). Таким образом, РФК-сигналинг одновременно определяет: 1) мобилизацию защитных систем растений в ответ на инвазию микопатогенов; 2) активацию роста и дифференцировки микопатогена в растительных тканях после инвазии; 3) мико- и фитотоксичность фунгицидов. Задача получения стабильно высоких урожаев зерна заключается в том, чтобы РФКзависимые перестройки этих трех систем привели к максимальному подавлению микоинфекции с минимальными фитотоксическими эффектами. Для решения этой задачи требуются адекватные и доступные модельные системы.

Наряду с уровнем продуктов перекисного окисления важным индикатором состояния корневой системы растений является содержание свободной аминокислоты пролина, которое является интегральным показателем активности антиоксидантных и защитных систем корня. Пролин выполняет функцию низкомолекулярного скавенджера свободных радикалов (Signorelli et al., 2014) и увеличивает экспрессию генов антиоксидантных ферментов (de Carvalho et al., 2013). Активация синтеза белков с высоким содержанием пролина играет важную роль в реализации механизмов защиты корня от инвазии патогенов (Cecchini et al., 2011; Plancot et al., 2013; Qamar et al., 2015).

С корнями связаны не только зоны инвазии патогенов (Berrocal-Lobo and Molina, 2008), но и система пограничных клеток (ПК). Эта специфическая популяция метаболически активных клеток локализуется в корневом апексе и играет фундаментальную роль в регуляции взаимоотношений корня с симбиотическими и патогенными организмами ризосферы (Gunawardena et al., 2002; Bais et al., 2006; Wen et al., 2007, 2009; Cannesan et al., 2011, 2012). Гелевый чехол является про- 
дуктом экскреторной активности ПК и средой их обитания после отделения от поверхности корневого апекса (Cannesan et al., 2011, 2012; Hawes, 2012). Инвазия патогенов в ткани корня инициирует продукцию ПК, увеличивает секреторную активность ПК (Plancot et al., 2013). Это позволяет рассматривать численность ПК как интегральный показатель активности систем защиты корня после инвазии патогенов.

Цель представленной работы - исследование гидропонной культуры Triticum aestivum в качестве модельной системы для оценки биологического действия фунгицидных препаратов. Для этого определяли содержание продуктов перекисного окисления белков (карбонилированных белков (КБ)) и липидов (малонового диальдегида (МДА)) и свободного пролина в корнях, численность ПК в корневом апексе неинфицированных проростков и проростков, инфицированных Fusarium graminearum, обработанных и не обработанных фунгицидом.

\section{Материалы и методы}

В эксперименте было пять вариантов: в контрольном варианте использовали неинфицированное зерно пшеницы T. aestivum, в четырех опытных вариантах - зерно, инфицированное $F$. graminearum. Зерно промывали в течение 5-6 ч под проточной водой и замачивали на 24 ч в дистиллированной воде при комнатной температуре. Проклюнувшиеся зерновки раскладывали по чашкам Петри по 50 штук в каждую. В контрольный вариант и в один из опытных вносили 7 мл дистиллированной воды, в три оставшихся опытных варианта - 7 мл раствора фунгицида тебуконазола (ТБ) с концентрацией 0,01 ; 0,10 и 1,00 мкг/мл. Зерно проращивали в течение 48-часов при комнатной температуре в условиях круглосуточной освещенности.
У 2-дневных проростков срезали фрагменты корней с корневыми апексами длиной в $1 \mathrm{~cm}$. Полученную биомассу корней гомогенизировали в 0,05 М Трис-HCl буфере, $\mathrm{pH}=7.4$, в ручном гомогенизаторе, при $\mathrm{T}=4^{\circ} \mathrm{C}$. Гомогенаты центрифугировали для удаления грубого дебриса при $5000 \mathrm{~g} 45$ мин при $\mathrm{T}=4{ }^{\circ} \mathrm{C}$. Супернатант собирали и использовали для определения содержания карбонилированных белков по методу Carty et al. (2000), малонового диальдегида по методу Heath and Packer (1968) и пролина по методу Bates et al. (1973). Содержание карбонилированных белков, малонового диальдегида и пролина пересчитывали на 1 мг белка гомогената корней. Белок определяли по методу Лоури (Lowry et al., 1951).

Для микроскопического анализа корневые апексы фиксировали 2,5\%-ным глутаровым альдегидом, приготовленном на 0,1 М фосфатном буфере, $\mathrm{pH}=7,2$. Корневые апексы отмывали от фиксатора дистиллированной водой и окрашивали $0,01 \%$-ным метиленовым синим. Под световым микроскопом подсчитывали количество свободных пограничных клеток, отделившихся от поверхности корневого апекса, и оценивали размеры гелевого чехла (за счет большого количества полисахаридов чехол окрашивался в голубой цвет). В каждом экспериментальном варианте анализировали 60-70 корневых апексов.

Эксперимент был проведен в двух повторностях с тремя биологическими повторами для каждой экспериментальной точки. На графиках и в таблице показаны средние и ошибки средних. Для оценки достоверности различий средних использовали критерий Стъюдента.

\section{Результаты и обсуждение}

В гидропонной культуре активность прорастания неинфицированных зерновок 
Triticum aestivum достигала $90 \pm 3 \%$ (прорастало $90 \%$ зерновок). В корнях 2-дневных проростков содержание КБ составляло $1,03 \pm 0,09$ нМ/мг белка (рис. 1). Содержание одного из продуктов перекисного окисления липидов, малонового диальдегида (МДА), составляло $0,300 \pm 0,035$ нМ/мг белка. МДА, как продукт перекисного окисления мембранных липидов, может участвовать в регуляции активности клеточных мембран (через реорганизацию липидного бислоя и изменение активности мембраносвязанных белков) (Ansari et al., 2015; Antosik et al., 2015). Выявленное соотношение содержания КБ и МДА представляет собой «физиологический фон», в условиях которого реализуется нормальное развитие проростков.

Содержание пролина в корнях 2-дневных проростков составляло 10,59 \pm 0,26 мкг/ мг белка. Выявленные соотношения в содержании КБ, МДА и пролина определяют особенности окислительно-восстановительного гомеостаза, характерного для нормально развивающихся корней неинфицированных проростков T. aestivum.
Для инфицированных $F$. graminearum зерновок активность прорастания составляла $77 \pm 7 \%$. Но при этом содержание КБ в корнях инфицированных проростков было в 8 раз больше, чем в корнях неинфицированных проростков (рис. 1). Увеличение активности перекисного окисления белков является результатом регулируемой активации продукции РФК в растительных тканях в ответ на инвазию микопатогена и необходимо для индукции РФК-зависимого сигналинга защитных систем (Frederickson et al., 2014; Swarupa et al., 2014). В отличие от значительного увеличения КБ содержание МДА в корнях инфицированных проростков достоверно не отличалось от содержания в неинфицированных корнях (рис. 1). Это может быть обусловлено включением МДА в окислительную модификацию белков (Augustyniak et al., 2015).

Содержание пролина в корнях инфицированных проростков было в 1,4 раза больше по сравнению с корнями неинфицированных проростков (рис. 1). Относительно небольшое увеличение содержания пролина (скавенджера свободных радикалов) может быть связано

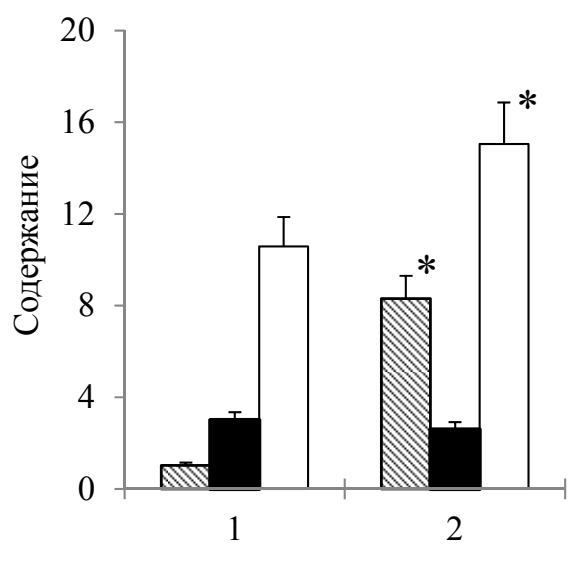

षКарб. белки $\mathbf{\square Д А ~ \square П р о л и н ~}$

Рис. 1. Содержание карбонилированных белков (карб. белки, нМ/мг белка), малонового диальдегида (МДА, $10^{-8} \mathrm{M} /$ мг белка) и пролина (мкг/мг белка) в корнях 2-дневных проростков Triticum aestivum. По оси абсцисс: 1 - неинфицированные проростки; 2 - проростки, инфицированные Fusarium graminearum. Звездочками отмечены значения варианта 2, достоверно отличающиеся от варианта 1, p>0,05

$$
-245-
$$


с участием пролина в активации более эффективных антиоксидантных систем (увеличении экспрессии генов аскорбат-пероксидазы, каталазы, супероксид-дисмутазы, глутатионредуктазы (de Carvalho et al., 2013)). Выявлено, что для корней инфицированных проростков характерны совершенно иные количественные соотношения между содержанием КБ, МДА и пролина, что может свидетельствовать о переходе окислительно-восстановительных систем на новый уровень гомеостаза.

Внесение в культуральную среду фунгицида тебуконазола (ТБ) в концентрациях 0,01 ; 0,10 и 1,00 мкг/мл не влияло на активность прорастания инфицированных зерновок по сравнению с инфицированным вариантом без внесения фунгицида (75 \pm 8 \%). Все изученные концентрации ТБ не влияли на содержание КБ, МДА и пролина в корнях инфицированных проростков по сравнению инфицированным вариантом без внесения фунгицида (таблица). Возможно, это было следствием относительно низких концентраций ТБ, использованных в эксперименте.

Далее изучали морфологические особенности корневого апекса неинфицированных и инфицированных проростков, характеризующихся выраженными различиями в содержании карбонилированных белков. На рис. 2 представлены микрофотографии популяции пограничных клеток (ПК), которая локализу- ется в корневом апексе растений. ПК играют важную роль в формировании химического и механического барьера, защищающего корневой апекс и его меристему от воздействия неблагоприятных факторов, в частности от инвазии различных патогенов. Этот барьер представляет собой гелевый чехол на поверхности корневого апекса.

Световая микроскопия корней неинфицированных проростков выявила следующие морфологические особенности корневого апекса. Корневой апекс окружен небольшим гелевым чехлом, в котором находятся ПК, утратившие механический контакт с поверхностью апекса (рис. 3а). Численность ПК для неинфицированных проростков невелика: $15 \pm 3$ кл/апекс. У инфицированных проростков высокое содержание карбонилированных белков в корнях сопровождалось увеличением численности ПК (47 \pm 7 кл/апекс). Это позволяет предположить, что РФК-сигналинг может включаться в активацию продукции ПК в ответ на инвазию микопатогенов. Одновременно с увеличением численности ПК в корневом апексе инфицированных проростков наблюдали увеличение размеров гелевого чехла (рис. 3б, в, г). Формирование объемного гелевого чехла обусловлено активацией экскреторной активности ПК и защищает корневой апекс от инвазии патогенов (корневой апекс - наиболее «защищенная» зона кор-

Таблица. Содержание карбонилированных белков (карб. белки, нМ/мг белка), малонового диальдегида (МДА, нМ/мг белка) и пролина (мкг/мг белка) в корнях 2-дневных проростков Triticum aestivum, инфицированных Fusarium graminearum, при проращивании в среде с различными концентрациями тебуконазола

\begin{tabular}{|c|c|c|c|c|}
\hline \multirow{2}{*}{$\begin{array}{c}\text { Содержание } \\
\text { в корнях }\end{array}$} & \multicolumn{4}{|c|}{ Концентрация фунгицида в среде, мкг/мл } \\
\cline { 2 - 5 } & 0 & 0,01 & 0,1 & 1 \\
\hline Карб. белки & $8,31 \pm 1,22$ & $8,98 \pm 0,96$ & $8,91 \pm 1,10$ & $9,05 \pm 1,53$ \\
\hline МДА & $0,261 \pm 0,031$ & $0,284 \pm 0,024$ & $0,281 \pm 0,028$ & $0,297 \pm 0,033$ \\
\hline Пролин & $15,05 \pm 1,85$ & $15,61 \pm 1,01$ & $16,82 \pm 1,65$ & $15,51 \pm 1,32$ \\
\hline
\end{tabular}




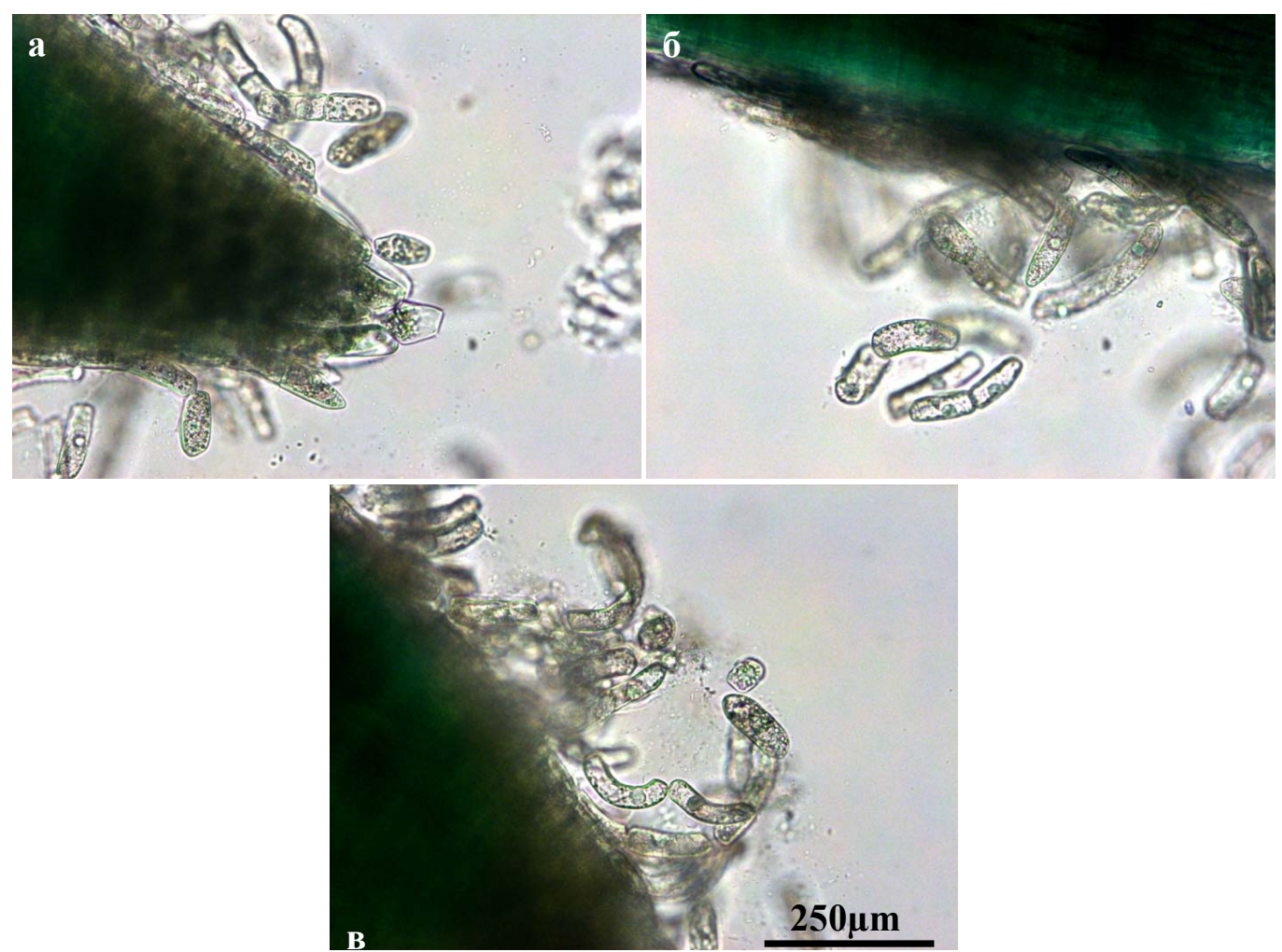

Рис. 2. Пограничные клетки корневого апекса 2-дневных проростков Triticum aestivum: а - одиночные клетки на вершине корневого апекса; б, в - агрегаты клеток на боковой поверхности корневого апекса. Клетки утратили механический контакт с поверхностью корневого апекса и лежат в гелевом чехле, окружающем корневой апекс

ня). Эффективность защиты определяется не только увеличением размеров гелевого чехла, но и изменениями его состава (Baetz and Martinoia, 2014). Известно, что в инфицированных корнях ПК секретируют ксилогалактураны, которые устойчивы к воздействию пектинолитических ферментов микопатогенов, и арабингалактановые белки (Cannesan et al., 2011, 2012).

Внесение фунгицида ТБ в среду не влияло на содержание КБ в корнях инфицированных проростков (по сравнению с инфицированными проростками без фунгицида), но приводило к дозозависимому уменьшению ПК в корневом апексе (рис. 4a). Так, для концентрации ТБ 0,01 и 0,10 мкг/мл количество ПК уменьшалось в 2 раза, для концентрации
ТБ 1,00 мкг/мл - в 4,7 раза по сравнению с вариантом без внесения фунгицида.

Уменьшение численности ПК в корневом апексе сопровождалось уменьшением размеров гелевого чехла. В варианте с концентрацией ТБ 1,00 мкг/мл преобладали практически «голые» корневые апексы, без заметного гелевого чехла и свободных ПК (рис. 4б, рис. 5). Такие «голые» апексы не встречались у неинфицированных проростков. Это позволяет предположить, что этот феномен обусловлен фитотоксичностью фунгицида. Диффундируя через гелевый чехол в корневой апекс, ТБ ингибирует продукцию ПК, возможно, через стерол-зависимый сигналинг, который участвует в регуляции активности пролиферации клеток (обзор Roy et al., 2011). Резкое сокра- 


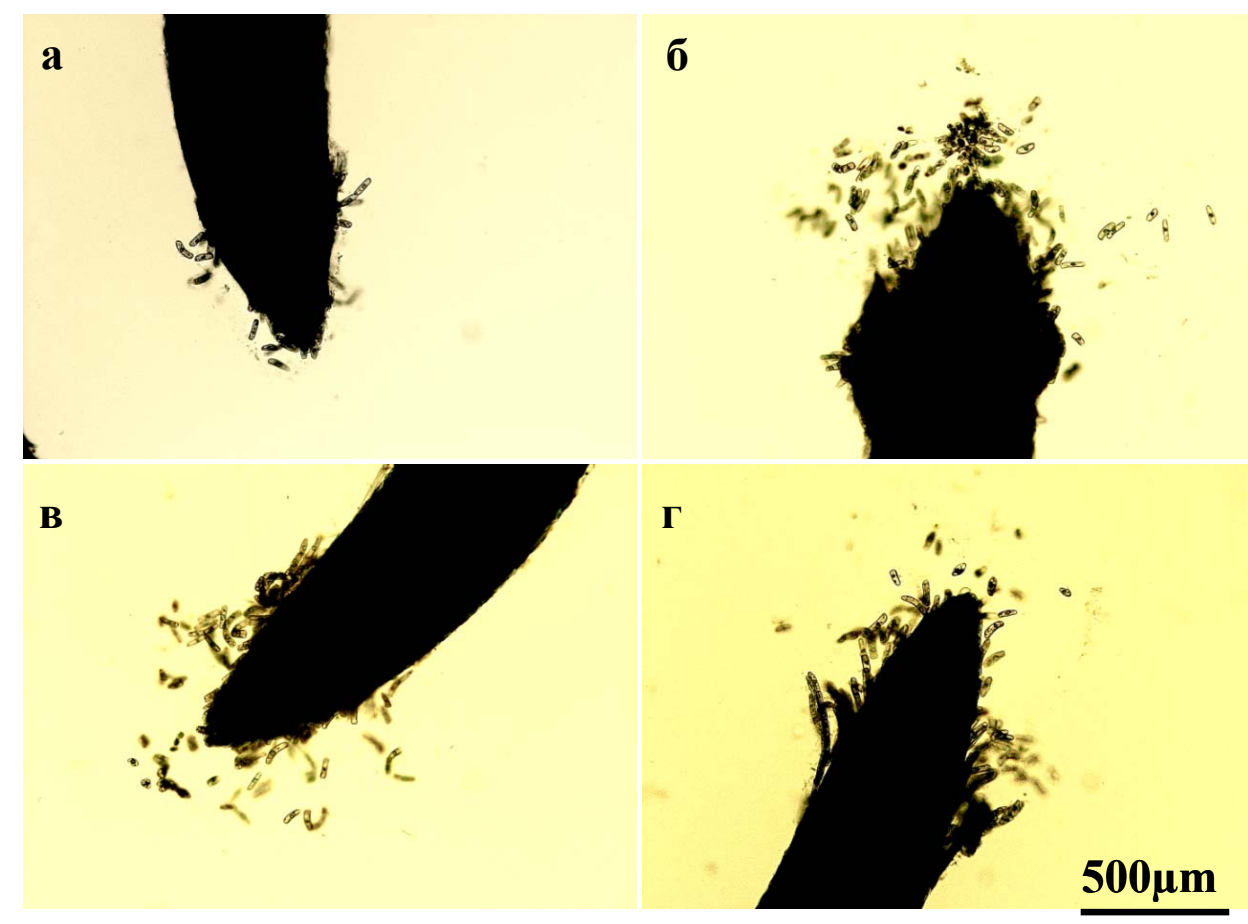

Рис. 3. Морфология корневых апексов 2-дневных проростков Triticum aestivum: $a$ - корневой апекс неинфицированных проростков; б, в, г - корневой апекс проростков, инфицированных Fusarium graminearum. Разброс пограничных клеток вокруг корневого апекса отражает размеры гелевого чехла. В апексах инфицированных проростков клетки в гелевом чехле могут находиться в составе крупных агрегатов (б), отслаиваться пластами с боковой поверхности корневого апекса (г).

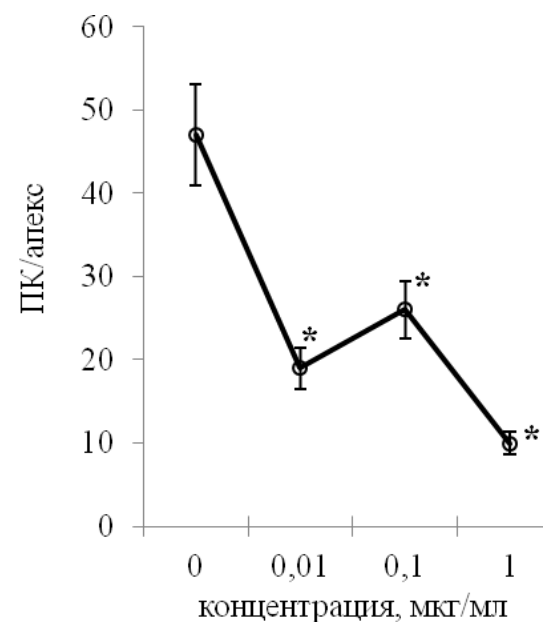

A

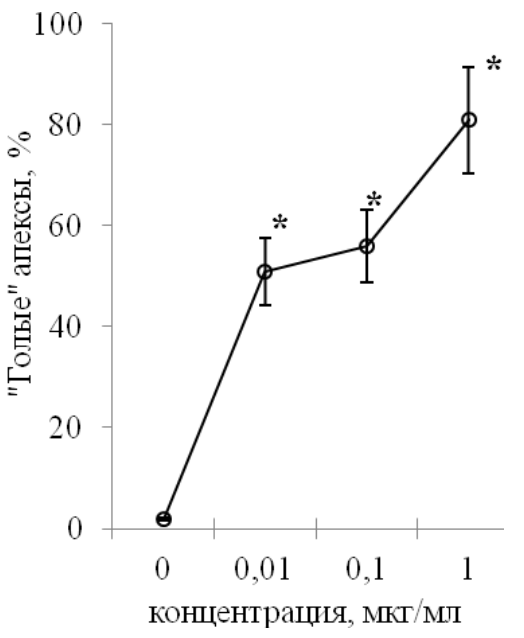

Б

Рис. 4. Количество пограничных клеток в корневом апексе (а) и относительное количество «голых» (без заметного гелевого чехла) апексов (б) у 2-дневных проростков Triticum aestivum, инфицированных Fusarium graminearum, при проращивании на среде с различными концентрациями тебуконазола. Звездочками отмечены значения, достоверно отличающиеся от варианта без внесения тебуконазола, $\mathrm{p}>0,05$ 


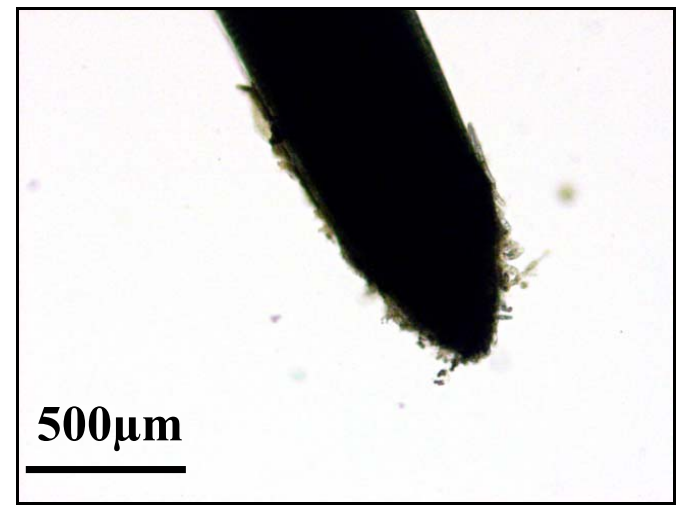

Рис. 5. «Голый» (без заметного гелевого чехла) корневой апекс - морфологический вариант корневого апекса, который появляется у инфицированных Fusarium graminearum 2-дневных проростков Triticum aestivum при проращивании на среде с различными концентрациями фунгицида тебуконазола

щение численности свободных ПК, основных продуцентов молекулярных компонентов гелевого чехла, приводит к появлению «голых» апексов. Трудно обсуждать последствия дисбаланса между высокой активностью продукции РФК в корнях инфицированных проростков и резким сокращением численности свободных ПК, исчезновением гелевого чехла. Можно полагать, что это может привести к снижению эффективности защитных систем растительных тканей в условиях фитопатогенной инвазии.

Несмотря на неопределенность молекулярно-клеточных механизмов, лежащих в основе выявленного феномена «голых» апексов, полученные результаты позволяют рассматривать популяцию ПК в качестве одной из эффекторных мишеней фунгицида ТБ и использовать ее для оценки фитотоксичности фунгицидов в гидропонной культуре.

\section{Заключение}

Показано, что в инфицированных $F$ graminearum 2-дневных проростках T. aestivum происходит резкое увеличение содержания карбонилированных белков в корнях, сопровождающееся увеличением численности ПК и размеров гелевого чехла в корневом апексе (по сравнению с неинфицированными проростками). Фунгицид тебуконазол в исследованных концентрациях не влиял на содержание карбонилированных белков в корнях инфицированных проростков, но приводил к резкому уменьшению численности ПК и размеров гелевого чехла (до полного исчезновения) в корневом апексе. Полученные результаты позволяют положительно оценить гидропонную культуру как модельную систему для оценки биологического действия фузариоза и фунгицидов,

Работа выполнена при поддержке Российского научного фонда по гранту № 14-2600039.

\section{Список литературы}

Ahemad M., Khan M.S. (2012a) Alleviation of fungicide-induced phytotoxicity in green gram [Vigna radiata (L.) Wilczek] using fungicide-tolerant and plant growth promoting Pseudomonas strain. Saudi Journal of Biological Sciences, 19(4): 451-459

$$
-249-
$$


Ahemad M., Khan M.S. (2012b) Effect of fungicides on plant growth promoting activities of phosphate solubilizing Pseudomonas putida isolated from mustard (Brassica compestris) rhizosphere. Chemosphere, 86(9): 945-950

Ansari F.A., Ali S.N., Mahmood R. (2015) Sodium nitrite-induced oxidative stress causes membrane damage, protein oxidation, lipid peroxidation and alters major metabolic pathways in human erythrocytes. Toxicology In Vitro, 29(7): 1878-1886

Antosik A., Czubak K., Gajek A., Marczak A., Glowacki R., Borowczyk K., Zbikowska H.M. (2015) Influence of pre-storage irradiation on the oxidative stress markers, membrane integrity, size and shape of the cold stored red blood cells. Transfusion Medicine and Hemotherapy, 42(3): 140-148

Augustyniak E., Adama A., Wojdyla K., Rogowska-Wrzesinska A., Willetts R., Korkmaz A., Atalay M., Weber D., Grune T., Borsa C., Gradinaru D., Chand Bollineni R., Fedorova M., Griffiths H.R. (2015) Validation of protein carbonyl measurement: a multi-centre study. Redox Biology, 4: 149157

Baetz U., Martinoia E. (2014) Root exudates: the hidden part of plant defence. Trends in Plant Science, 19: 90-98

Bais H.P., Weir T.L., Perry L.G. (2006) The role of root exudates in rhizosphere interactions with plants and other organisms. Annual Review of Plant Biology, 57: 233-266

Bates L.S., Waldren R.P., Teare I.D. (1973) Rapid determination of free proline for water stress studies. Plant and Soil, 39(1): 205-207

Berrocal-Lobo M., Molina A. (2008) Arabidopsis defense response against Fusarium oxysporum. Trends in Plant Science, 13: 145-150

Cannesan M.A., Gangneux C., Lanoue A., Giron D., Laval K., Hawes M., Driouich A., VicréGibouin M. (2011) Association between border cell responses and localized root infection by pathogenic Aphanomyces euteiches. Annals of Botany, 108: 459-469

Cannesan M.A., Durand C., Burel C., Gangneux C., Lerouge P., Ishii T., Laval K., Fllet-Gueye M.L., Driouich A., Vicré-Gibouin M. (2012) Effect of arabinogalactan proteins from the root caps of pea and Brassica napus on Aphanomyces euteiches zoospore chemotaxis and germination. Plant Physiology, 159: 1658-1670

de Carvalho K., de Campos M.K., Domingues D.S., Pereira L.F., Vieira L.G. (2013) The accumulation of endogenous proline induces changes in gene expression of several antioxidant enzymes in leaves of transgenic Swingle citrumelo. Molecular Biology Reports, 40(4): 3269-3279

Carty J.L., Bevan R., Waller H., Mistry N., Cooke M., Lunec J., Griffiths H.R. (2000) The effects of vitamin $\mathrm{C}$ supplementation on protein oxidation in healthy volunteers. Biochemical and Biophysical Research Communications, 273 (2): 729-735

Cecchini N.M., Monteoliva M.I., Alvarez M.E. (2011) Proline dehydrogenase contributes to pathogen defense in Arabidopsis. Plant Physiology, 155: 1947-1959.

Frederickson D.E.M., Loake G.J. (2014) Redox regulation in plant immune function. Antioxidants and Redox Signaling, 21(9): 1373-1388

Gunawardena U., Hawes M.C. (2002) Tissue specific localization of root infection by fungal pathogens: role of root border cells. Molecular Plant-Microbe Interactions: MPMI, 15: 1128-1136

Hawes M.C. (2012) Roles of root border cells in plant defense and regulation of rhizosphere microbial populations by extracellular DNA 'trapping'. Plant and Soil, 355: 1-16 
Hartwig T., Corvalan C., Best N.B., Budka J.S., Zhu J.Y., Choe S., Schulz B. (2012) Propiconazole is a specific and accessible brassinosteroid (BR) biosynthesis inhibitor for Arabidopsis and maize. PLoS ONE, 7(5): e36625. doi: 10.1371/journal.pone.0036625

Heath R.L., Packer L. (1968) Photoperoxidation in isolated chloroplasts. I. Kinetics and stoichiometry of fatty acid peroxidation. Archives of Biochemistry and Biophysics, 125(1): 189-198

Lamb D.C., Cannieux M., Warrilow A.G., Bak S., Kahn R.A., Manning N.J., Kelly D.E., Kelly S.L. (2001) Plant sterol 14a-demethylase affinity for azole fungicides. Biochemical and Biophysical Research Communications, 284: 845-849

Lowry O.H., Rosebrough N.J., Farr A.L., Randall R.J. (1951) Protein measurement with the Folin phenol reagent. The Journal of Biological Chemistry, 193(1): 265-275

Qamar A., Mysore K.S., Senthil-Kumar M. (2015) Role of proline and pyrroline-5-carboxylate metabolism in plant defense against invading pathogens. Frontiers in Plant Science, 6: 503. doi: 10.3389/fpls.2015.00503

Park S.Y., Lee J.S., Ko Y.J., Kim A.R., Choi M.K., Kwak M.K., Choi H.G., Yong C.S., Kim J.A. (2008) Inhibitory effect of simvastatin on the TNF-alpha- and angiotensin II-induced monocyte adhesion to endothelial cells is mediated through the suppression of geranylgeranyl isoprenoiddependent ROS generation. Archives of Pharmacol Research, 31(2): 195-204

Plancot B., Santaella C., Jaber R., Kiefer-Meyer M.C., Follet-Gueye M.L., Leprince J., Gattin I., Souc C., Driouich A., Vicré-Gibouin M. (2013) Deciphering the responses of root border-like cells of Arabidopsis and flax to pathogen-derived elicitors. Plant Physiology, 163: 1584-1597

Roy M., Kung H.J., Ghosh P.M. (2011) Statins and prostate cancer: role of cholesterol inhibition vs. prevention of small GTP-binding proteins. American Journal of Cancer Research, 1(4): 542-461

SANCO (2013) Document No. SANCO/12571/2013. EU Pesticide Database, 37-40

Schmale D.G., Bergstrom G.C. (2003) Fusarium head blight in wheat. The Plant Health Instructor. DOI:10.1094/PHI-I-2003-0612-01

Serra A.A., Nuttens A., Larvor V., Renault D., Couée I., Sulmon C., Gouesbet G. (2013) Low environmentally relevant levels of bioactive xenobiotics and associated degradation products cause cryptic perturbations of metabolism and molecular stress responses in Arabidopsis thaliana. Journal of Experimental Botany, 64(10): 2753-2766

Serra A.A., Couée I., Renault D., Gouesbet G., Sulmon C. (2015) Metabolic profiling of Lolium perenne shows functional integration of metabolic responses to diverse subtoxic conditions of chemical stress. Journal of Experimental Botany, 66(7): 1801-1816

Signorelli S., Coitiño E.L., Borsani O., Monza J. (2014) Molecular mechanisms for the reaction between (')OH radicals and proline: insights on the role as reactive oxygen species scavenger in plant stress. The Journal of Physical Chemistry. B, 118(1): 37-47

Swarupa V., Ravishankar K.V., Rekha A. (2014) Plant defense response against Fusarium oxysporum and strategies to develop tolerant genotypes in banana. Planta, 239: 735-751

Takemoto D., Tanaka A., Scott B. (2007) NADPH oxidases in fungi: diverse roles of reactive oxygen species in fungal cellular differentiation. Fungal Genetics and Biology: FG \& B, 44: 10651076

Wassmann S., Laufs U., Bäumer A.T., Müller K., Konkol C., Sauer H., Böhm M., Nickenig G. (2001) Inhibition of geranylgeranylation reduces angiotensin II-mediated free radical production in 
vascular smooth muscle cells: involvement of angiotensin AT1 receptor expression and Rac1 GTPase. Molecular Pharmacology, 59(3): 646-654

Wen F., Van Etten H.D., Tsaprailis G., Hawes M.C. (2007) Extracellular proteins in pea root tip and border cell exudates. Plant Physiology, 143: 773-783

Wen F., White G.J., Van Etten H.D., Xiong Z., Hawes M.C. (2009) Extracellular DNA is required for root tip resistance to fungal infection. Plant Physiology, 151: 820-829

Yang D., Wang N., Yan X., Shi J., Zhang M., Wang Z., Yuan H. (2014) Microencapsulation of seed-coating tebuconazole and its effects on physiology and biochemistry of maize seedlings. Colloids and Surfaces. B, Biointerfaces, 114: 241-246 